\title{
Studi Deskriptif Kompetensi Kepribadian Konselor yang Diharapkan Siswa
}

\author{
Heru Andrian Fatmawijaya \\ SMA NW Narmada \\ Wirabakti Narmada, Lombok Barat, NTB, Indonesia \\ Email: heruandrian05@gmail.com
}

\begin{abstract}
This study aims to explore the high qualified counselors' personal competence at SMA Negeri 11 Yogyakarta. This research is a descriptive research. The participants of this research were 169 students consisting of class X, XI and XII class selected by simple random sampling. The instrument for the data collection is questionnaires of counselors' personal competence. There are four aspects that were outlined in the questionnaires namely, godly and devoted to the Almighty God, respect and uphold the values of humanity, individualist and independent, having integrity and stability of a strong personality, having high performance quality. The data analysis techniques used a simple calculation in which grouping the data into three criterias, they are, poor, moderate, and good. The results showed that the expected counselors' personal competence at SMA Negeri 11 Yogyakarta reaching the score of each are 50.3\% in good criteria, $49.7 \%$ in moderate citeria and $0 \%$ in poor criteria.The results of this study can be used as the basis for the development of counselors' personal competence in order to become high qualifeid counselors as expected by the students. The counselors who have a strong personality as the expected by students can improve students' enthusiasm to acquire the guidance and counseling services at schools.
\end{abstract}

Keywords: personal competence counselor, descriptive studies, simple random sampling

Tujuan penelitian ini untuk mengetahui kompetensi kepribadian konselor yang diharapkan siswa SMA Negeri 11 Yogyakarta. Penelitian ini merupakan jenis penelitian deskriptif. Subjek dalam penelitian ini berjumlah 169 siswa yang diambil melalui teknik simple random sampling. Instrumen pengumpulan data menggunakan angket kompetensi kepribadian konselor. Terdapat empat aspek yang diungkap dalam angket kompetensi kepribadian koonselor yang diharapkan siswa, yakni beriman dan bertakwa kepada Tuhan yang Maha Esa, menghargai dan menjunjung tinggi nilai-nilai kemanusiaan, individualitas dan kebebasan memilih, menunjukkan integritas dan stabilitas kepribadian yang kuat, dan menampilkan kinerja berkualitas. Teknik analis data yang digunakan dengan cara penghitungan sederhana melalui pengelompokan kriteria kurang, sedang, dan baik. Hasil penelitian menunjukkan kompetensi kepribadian konselor yang diharapkan siswa di SMA Negeri 11 Yogyakarta diperoleh data sebesar 50,3\% berada pada kategori baik dan sebesar 49,7\% berada pada kategori sedang. Hasil penelitian ini dapat dijadikan sebagai dasar pengembangan kompetensi kepribadian konselor agar menjadi konselor yang diharapkan oleh siswa. Konselor yang memiliki kepribadian sesuai harapan siswa dapat meningkatkan antusias siswa untuk mendapatkan layanan bimbingan dan konseling di sekolah.

Kata kunci: kompetensi kepribadian konselor, studi deskriptif, simple random sampling

\section{Pendahuluan}

Layanan bimbingan dan konseling merupakan layanan yang diperuntukkan bagi siswa, baik bagi siswa yang mempunyai masalah maupun siswa yang tidak mempunyai masalah. Layanan bimbingan dan konseling di sekolah sebagai upaya dari guru bimbingan dan konseling untuk membantu siswa dalam mengoptimalkan potensi dan memandirikan setiap siswa untuk menyelesaikan masalah-masalah yang dialaminya, baik masalah dalam bidang pribadi, bidang sosial, bidang akdemik, maupun bidang karir. Guru bimbingan dan konseling/konselor bertanggung jawab sepenuhnya dalam memberikan pelayanan bimbingan dan konseling kepada siswa dengan mencermati dampak jangka panjang dari pelayanan yang diberikan kepada siswa.

Dalam rangka mewujudkan pelayanan bimbingan dan konseling secara optimal, maka dalam pelayanan bimbingan dan konseling haruslah diberikan oleh guru bimbingan dan konseling yang professional, serta juga harus terlihat eksistensi dirinya sebagai pribadi jujur, berakhlak mulia dan menjadi suri teladan bagi siswa dan masyarakat. Menurut Tohirin (2009: 119) seorang guru pembimbing bisa menjadi model atau contoh yang baik bagi penyelesaian masalah siswa. Guru 


\section{FATMAWIJAYA}

pembimbing dapat menjadi contoh yang efektif bagi pemecahan masalah siswa. Guru pembimbing tidak akan dapat menjalankan fungsi ini apabila dirinya tidak memiliki kepribadian yang baik.

Konselor yang menguasai kompetensi kepribadian dengan baik tentunya dapat menjadi contoh atau model yang baik pula kepada konseli, di samping itu konselor yang menguasai kompetensi kepribadian dengan baik menunjang keberhasilan pelayanan bimbingan dan konseling dalam membantu siswa dalam mengentaskan masalah pribadinya. Hal ini terlihat dalam salinan Peraturan Menteri Pendidikan Nasional Nomor 27 Tahun 2008 bahwa unjuk kerja guru bimbingan dan konseling/Konselor harus dilandasi oleh sikap, nilai dan kecendrungan pribadi yang mendukung.

Tugas utama konselor adalah dapat mengentaskan masalah-masalah pribadi siswa yang berkaitan dengan masalah dalam pendidikan dan pelajaran. Untuk membantu permasalahan tersebut seorang konselor tentunya harus memiliki pribadi yang mantap, stabil, dewasa, arif, dan berwibawa. Konselor juga haruslah individu yang memiliki pribadi yang stabil secara emosional sehingga mampu membimbing siswa secara efektif. Disamping itu, seorang konselor haruslah memiliki kompetensi akademik dan professional sebagai suatu keutuhan, sebagaimana dijelaskan dalam Permendiknas nomor 27 tahun 2008, tentang standar kualifikasi akademik dan kompetensi konselor dijelaskan bahwa, dalam kompetensi kepribadian konselor harus memiliki kepribadian yang meliputi beriman dan bertakwa kepada Tuhan Yang Maha Esa, menghargai dan menjunjung tinggi nilai-nilai kemanusiaan, individualitas dan kebebasan memilih, menunjukkan integritas dan stabilitas kepribadian yang kuat, menampilkan kinerja berkualitas tinggi.

Hasil penelitian yang dilakukan Rahmat Hidayat (2013) tentang persepsi siswa terhadap pribadi konselor yang diharapkan siswa menunjukkan ada problematika yang dialami konselor terhadap persepsi siswa. Kurangnya kompetensi kepribadian konselor konselor yang dilihat dari hasil penelitian tersebut, menunjukkan bahwa siswa tidak setuju pada point ketiga yaitu pada indikator jujur. Hal itulah mendorong peneliti untuk melakukan penelitian serupa di tempat yang berbeda yaitu di kota Yogyakarta. Berdasarkan hasil studi terdahulu melalui pengalaman praktik lapangan, peneliti melakukan wawancara terbatas kepada siswa pada tanggal 18 Juli 2014 di
SMA Negeri 11 Yogyakarta. Dari hasil wawancara peneliti dengan dua orang siswa, siswa tersebut menyatakan bahwa guru bimbingan dan konseling masih kurang menunjukkan integritas dan stabilitas kepribadian yang kuat, yaitu menampilkan kepribadian yang terpuji (seperti berwibawa, jujur, sabar, ramah, dan konsisten), siswa enggan untuk mendatangi ruangan bimbingan dan konseling yang ada di sekolah secara inisiatif dan mandiri, alasannya dikarenakan siswa masih takut kepada konselor.

Dari hasil wawancara yang peneliti lakukan pada tanggal 18 Juli 2014 pada 7 orang siswa di SMA N 11 Yogyakarta, memperoleh informasi bahwa menurut siswa konselor dirasa masih kurang menunjukkan sikap kepribadian yang hangat dan menyenagkan, alasannya karena masih dianggap tidak ramah dan sering bertanya, memberikan pertanyaan-pertanyaan yang membuat siswa merasa malu dan tertekan oleh pernyataan yang ditujukan kepadanya. Selian itu, menurut keterangan siswa bahwa, pada saat proses konseling konselor membandingkan siswa yang miskin dan kaya, antara siswa berprestasi dan tidak. Konselor selalu menyebutkan status sosial orang tua siswa pada saat siswa diminta menemui konselor.

Berdasarkan permasalahan yang telah dikemukakan di atas maka fokus dalam penelitian ini adalah studi deskriptif kompetensi pribadi konselor yang diharapkan siswa di SMA Negeri 11 Yogyakarta. Kepribadian konselor merupakan aspek penting yang harus dimiliki oleh seorang konselor karena dapat mempengaruhi keberhasilan dalam proses konseling dan dapat mempengaruhi kenyamanan serta keterbukaan siswa pada saat diberikan layanan bimbingan dan konseling.

Penelitian ini bertujuan untuk mengetahui kompetensi kepribadian konselor yang diharapkan siswa. Pentingya kompetensi kepribadian konselor berdampak pada proses dan hasil dari pelaksanaan layanan bimbingan dan konseling, sehingga kompetensi kepribadian konselor penting dikembangkan oleh konselor. Informasi yang diperoleh dari hasil penelitian ini dapat dijadikan sebagai dasar pengembangan kompetensi kepribadian bagi konselor agar dapat menjadi pribadi konselor yang diminati oleh para siswa, sehingga siswa merasa antusias untuk mendapatkan layanan bimbingan dan konseling di sekolah. 


\section{KOMPETENSI KEPRIBADIAN KONSELOR}

\section{Kajian Literatur}

\section{Kompetensi Kepribadian Konselor}

Rumusan standar kompetensi konselor telah dikembangkan dan dirumuskan atas dasar kerangka pikir yang menegaskan konteks tugas dan ekspektasi kinerja konselor. dalam kebijakan nasional, pemerintah telah merumuskan empat jenis kompetensi yang harus dimiliki seorang konselor, sebagaimana tercantum dalam penjelasan Peraturan Pemerintah No. 19 Tahun 2005 tentang standar nasional pendidikan, yaitu kompetensi pedagogis, kepribadian, sosial, dan profesional. Seorang konselor yang profesional diharapkan dapat menjalankan tugasnya secara profesional dengan memiliki dan menguasai keempat kompetensi tersebut. Dari empat kompetensi yang harus dimiliki konselor tersebut dalam hal ini yang menjadi fokus pembahasan yaitu kompetensi kepribadian konselor.

Seorang guru bimbingan dan konseling atau konselor harus memiliki kepribadian yang baik. Pelayanan bimbingan dan konseling berkaitan dengan pembentukan prilaku dan kepribadian klien. Melalui konseling diharapkan terbentuk prilaku positif (akhlak baik) dan kepribadian yang baik pula dalam diri klien. Upaya ini akan efektif apabila dilakukan oleh seseorang yang memiliki kepribadian yang baik pula (Tohirin, 2007: 117). Hikmawati (2010: 57) berpendapat bahwa kompetensi kepribadian konselor adalah kemampuan kepribadian yang mantap, stabil, berwibawa, menjadi teladan bagi peserta didik, dan berakhlak mulia.

Menurut Musfah (2011: 42) Kompetensi kepribadian, yaitu kemampuan kepribadian yang memiliki akhlak mulia, menampilkan kepribadian yang mantap, stabil, dan dewasa. Dapat bersikap arif dan bijaksana, mampu menjadi teladan bagi siswa, serta senantiasa mengevaluasai kinerja sendiri untuk mengembangkan diri sebagai makhluk yang religious.

Menurut Sukardi dan Kusmawati (2008: 31), beberapa kompetensi pribadi yang semestinya ada pada seorang guru, yaitu memiliki pengetahuan tentang materi pelajaran yang menjadi tanggung jawabnya. Selain itu, mempunyai pengetahuan tentang perkembangan peserta didik serta kemampuan untuk memperlakukan mereka secara individual.

Berdasarkan uraian diatas, dapat ditarik kesimpulan tentang kompetensi kepribadian konselor, guru bimbingan dan konseling atau konselor dapat dikatakan memiliki kompetensi kepribadian apabila seorang konselor memiliki perilaku yang baik, dapat menampilkan sikap kepribadian terpuji dan memiliki kemampuan untuk mengevaluasi kinerjanya sendiri.

Berdasarkan Permendiknas No.27 Tahun 2008, tentang standar kualifikasi akademik dan kompetensi konselor, Hidayat dan Herdi (2013: 117) mengidentifikasi beberapa kompetensi kepribadian yang harus dimiliki konselor. Pertama, beriman dan bertakwa kepada Tuhan Yang Maha Esa. Supriatna (2011: 22) mengemukakan beriman dan bertakwa kepada Tuhan Yang Maha Esa, hendaknya tampil dalam berprilaku keseharian seorang konselor dalam memperlakukan klien, dan dalam pengambilan keputusan ketika merancang pendekatan yang dipergunakan. Penelitian yang dilakukan oleh Rosniati Hakim (2013: 310) tentang "studi islam tentang akhlak konselor" diperoleh hasil bahwa di antara karakteristik dasar orang-orang beriman dan bertakwa menurut al-Qur'an adalah akhlak. Akhlak itu adalah ajaran dasar agama Islam yang wajib diketahui, dipahami, dihayati, dan diamalkan nilai-nilainya dalam kehidupan seharihari, baik secara pribadi maupun secara sosial. Berdasarkan hasil penelitian yang dilakukan oleh Sisrianti (2013: 35), tentang "persepsi siswa tentang kompetensi kepribadian guru bimbingan dan konseling/konselor di SMP N 5 Pariaman" terungkap bahwa persepsi siswa tentang kompetensi kepribadian guru bimbingan dan konseling/Konselor dilihat dari beriman dan bertakwa kepada Tuhan Yang Maha Esa. sebanyak $83,60 \%$. Hal ini berarti persepsi siswa tentang kompetensi kepribadian guru bimbingan dan konseling/Konselor dilihat dari beriman dan bertakwa kepada Tuhan Yang Maha Esa berada pada kategori baik. Beriman dan bertakwa kepada Tuhan Yang Maha Esa ini ditinjau dari beberapa aspek yakni: menampilkan kepribadian yang beriman dan bertakwa kepada Tuhan Yang Maha Esa, konsisten dalam menjalankan kehidupan beragama dan toleran terhadap pemeluk agama lain, berakhlak mulia dan berbudi pekerti luhur.

Kedua, menghargai dan menjunjung tinggi nilainilai kemanusiaan, individualitas dan kebebasan memilih. Mamat Supriatna (Sisrianti 2013: 36) mengemukakan bahwa seorang guru bimbingan dan konseling/konselor tidak memperlakukan memperlakukan siswa sebagai kliennya semena- 


\section{FATMAWIJAYA}

mena sesuai rasa senangnya sebagai seorang guru bimbingan dan konseling/konselor, tetapi guru bimbingan dan konseling/konselor memperlakukan siswanya sebagai individu yang memiliki potensi, moral, dan spiritual. Pendapat selanjutnya dikemukakan oleh Kunandar (Sisrianti 2013: 36) bahwa dalam hal ini guru bimbingan dan konseling/konselor tidak bersifat otoriter kepada siswa, misalnya dalam konseling perorangan seorang guru bimbingan dan konseling/konselor harus memberikan kebebasan kepada siswa untuk mengambil keputusan yang terbaik untuk dirinya selain dari adanya aturan-aturan tertentu. Berdasarkan hasil penelitian yang dilakukan oleh Sisrianti (2013: 35-36) tentang "persepsi siswa tentang kompetensi kepribadian guru bimbingan dan konseling/konselor di SMP N 5 Pariaman" diperoleh hasil diantaranya persepsi siswa tentang kompetensi kepribadian guru bimbingan dan konseling/konselor dilihat dari menghargai dan menjunjung tinggi nilai-nilai kemanusiaan, individualitas dan kebebasan memilih sebanyak $79,83 \%$. Hal ini berarti persepsi siswa tentang kompetensi kepribadian guru bimbingan dan konseling/konselor dilihat dari menghargai dan menjunjung tinggi nilai-nilai kemanusiaan, individualitas dan kebebasan memilih berada pada kategori cukup baik.

Ketiga, menunjukkan integritas dan stabilitas kepribadian yang kuat. Bahri (Sisrianti, 2013: 36) mengemukakan bahwa guru bimbingan dan konseling/konselor harus menampilkan kepribadian yang baik, tidak saja ketika melaksanakan tugasnya di sekolah, tetapi di luar sekolahpun guru harus menampilkan kepribadian yang baik, hal ini untuk menjaga wibawa dan citra guru sebagai pendidik yang selalu ditiru oleh masyarakat. Berdasarkan hasil penelitian yang dilakukan oleh Rahmat Hidayat (2013), tentang persepsi siswa terhadap pribadi konselor yang diharapkan siswa diperoleh hasil yaitu, pada indikator berwibawa responden menyatakan setuju dengan persentase sebasar $98,5 \%$. Kedua, yaitu pada indikator ramah responden menyatakan setuju dengan persentase sebesar 97,3\%. Ketiga pada indikator sabar siswa menyatakan setuju dengan persentase sebesar $93 \%$. Berdasarkan hasil penelitian tersebut yaitu konselor dalam aspek ini telah menunjukkan integritas dan stabilitas yang kuat ditinjau dari beberapa aspek yakni: menampilkan kepribadian dan perilaku yang terpuji (seperti berwibawa, jujur, sabar, ramah dan konsisten), menampilkan emosi yang stabil, peka bersikap empati, serta menghormati keragaman dan perubahan, menampilkan toleransi tinggi terhadap konseli yang menghadapi stress dan frustasi, menampilkan kinerja berkualitas tinggi dengan aspek menampilkan tindakan yang cerdas, kreatif, inovatif, dan produktif, bersemangat, berdisiplin dan mandiri, berpenampilan menarik dan menyenangkan, dan berkomunikasi secara efektif. Senada dengan pendapat di atas, Hikmawati (2010: 56-57) juga mengemukakan bahwa kepribadian konselor, antara lain:

1. Menampilkan keutuhan kepribadian konselor
a. Menampilkan perilaku membantu berdasarkan keimanan dan ketakwaan kepada Tuhan Yang Maha Esa.
b. Mengkomunikasikan secara verbal dan atau non verbal minat yang tulus dalam membantu orang lain.
c. Mendemonstrasikan sikap hangat dan penuh perhatian.

d. Secara verbal dan nonverbal mampu mengomunikasikan rasa hormat konselor terhadap klien sebagai pribadi yang berguna dan bermartabat.

e. Mengkomunikasikan harapan, mengekspresikan keyakinan bahwa klien mempunyai kapasitas untuk memecahkan problem, mengatur dan menata dirinya, dan berkembang.

f. Mendemonstrasikan sikap empati dan atribusi secara tepat.

g. Mendemonstrasikan integritas dan stabilitas kepribadian serta kontrol diri yang baik

h. Memiliki toleransi yang tinggi terhadap stress dan frustasi.

i. Mendemonstrasikan berfikir positf terhadap orang lain dan lingkungannya.

2. Berperilaku etik dan professional

a. Menyadari bahwa nilai-nilai pribadi konselor dapat mempengaruhi responsrespons konselor terhadap klien.

b. Menghindari sikap-sikap prasangka dan pikiran-pikiran stereotipe terhadap klien.

c. Tidak memaksakan nilai-nilai pribadi konselor terhadap klien.

d. Memahami kekuatan dan keterbatasan personal dan professional.

e. Mengelola diri secara efektif.

f. Bekerjasama secara produktif dengan teman sejawat dan anggota profesi lain.

g. Secara konsisten menampilkan perilaku sesuai dengan kode etik profesi. 


\section{KOMPETENSI KEPRIBADIAN KONSELOR}

Berdasarkan penjelasan di atas mengenai subimbingan dan konselingompetensi dan indikator kompetensi kepribadian konselor. Kemampuan yang harus dimiliki oleh seorang konselor ialah dapat menjadi teladan dan panutan bagi siswa terhadap sifat dan kualitas kepribadian konselor. Sifat dan kualitas pribadi seorang konselor dapat berpengaruh langsung terhadap keberhasilan proses konseling, mengingat sifat kepribadian konselor menjadi faktor penentu bagi pencapaian proses konseling yang efektif.

Menurut Yusuf dan Juntika (2010: 37) dalam kenyataan di lapangan, tidak sedikit siswa yang mau datang ke ruang bimbingan dan konseling, bukan karena guru pembimbing yang kurang keilmuannya dalam bidang bimbingan, tetapi karena mereka memiliki kesan bahwa pembimbing judes atau kurang ramah. Konselor yang memiliki dan kompetensi kepribadian konselor dan mampu bersikap baik dan professional tentunya bermanfaat dan berpengaruh bagi proses konseling yang dilakukan oleh konselor kepada konseli. Adapun sifat yang harus dikuasai pada seorang konselor dalam proses bantuan kepada konseli.

Carlekhuff (Gunawan, 2001: 232) menyebutkan sembilan sifat kepribadian dalam diri konselor yang dapat menumbuhkan kesadaran orang lain dalam proses konseling yaitu:

1. Empati

Empati adalah kemampuan konselor untuk merasakan secara tepat apa yang dirasakan dan dialami oleh orang lain dan mengkomunikasikan persepsinya. Orang yang memiliki tingkat empati tinggi akan menampakkan sifat bantuannya yang nyata dan berarti dalam hubungannya dengan orang lain, sementara mereka yang rendah empatinya menunjukkan sifat yang secara nyata dan berarti merusak hubungan antar pribadi. Karakteristik kepribadian seorang keonselor adalah salah satunya terletak pada kemampuannya berempati, konselor yang telah menguasai kompetensi kepribadian secara baik tentunya dapat berkomunikasi dengan klien dan dapat merasakan apa yang dirasakan oleh klien dengan baik.

2. Respek

Respek menunjukkan secara tak langsung bahwa konselor menghargai martabat dan nilai konseli sebagai manusia. Hal ini mengandung arti juga bahwa konselor menerima kenyataan: setiap konseli mempunyai hak untuk memilih sendiri, memiliki kebebasan, kemauan, dan mampu membuat keputusannya sendiri. Pada tingkat respek rendah, seorang konselor tidak mempunyai respek terhadap konseli, ia sering memberikan perlindungan berlebih-lebihan, merendahkan ataun bahkan memberikan penilaian terlalu rendah.

3. Keaslian (Genuiness)

Keaslian merupakan kemampuan konselor menyatakan dirinya secara bebas dan mendalam tanpa pura-pura, tidak bermain peranan dan tidak mempertahankan diri. Konselor yang demikian selalu tampak keaslian pribadinya, sehingga tidak ada pertentangan antara apa yang ia katakana dan apa yang ia lakukan. Tingkah lakunya sederhana, lugu dan wajar.

4. Kekongkretan (Concreteness)

Kekongkretan menyatakan ekspresi yang khusus mengenai perasaan dan pengalaman orang lain. Seorang konselor yang memiliki kekongkretan tinggi selalu memelihara hubungan khusus dan selalu mencari jawaban mengenai apa, mengapa, kapan, dimana dan bagaimana dari sesuatu yang ia hadapi. Konselor yang memiliki kekongkretan selalu memelihara keserasian dalam hubungannya dengan orang lain dan mencegah konseli melahirkan diri dari masalah yang dihadapinya.

5. Konfrontasi (Confrontation)

Konfrontasi terjadi jika terdapat kesenjangan dengan apa yang dikatakan konseli dengan apa yang ia alami, atau antara yang ia katakana pada suatu saat dengan apa yang dikatakan sebelum itu. Variable ini tidak dikontrol sepenuhnya oleh konselor, tetapi hal ini dapat dilaksanakan jika konselor merasakan cocok untuk dikonfrontasikan. Dalam situasi konseling umpamanya terdapat banyak macam kemungkinan untuk konfrontasi.

6. Membuka Diri (Self-Disclosure)

Membuka diri adalah penampilan perasaan, sikap, pendapat, dan pengalamanpengalaman pribadi konselor unuk kebaikan konseli. Konselor mengungkapkan diri sendiri dan membagikan dirinya kepada konseli dengan mengungkapkan beberapa pengalaman yang berarti yang bersangkutan dengan masalah konseli. Pada tingkat pengungkapan diri yang rendah, konselor tidak pernah menampilkan dirinya dan bahkan membuat 


\section{FATMAWIJAYA}

batas untuk menutupi diri sendiri atau menetralisir.

7. Kesanggupan (Potency)

Wolf, 1970 (dalam Gunawan, 2001: 239) dinyatakan sebagai karisma, sebagai suatu kekuatan yang dinamis dan magnetis dari kualitas pribadi konselor. Konselor yang memiliki sifat potensi ini selalu menampakkan kekuatannya dalam penampilan pribadinya. Ia dengan jelas tampak menguasai dirinya dan ia mampu menyalurkan kompetensinya dan rasa aman kepada konseli.

8. Kesiapan (Immediacy)

Tingkat kesiapan yang tinggi terdapat pada diskusi dan analisis yang terbuka mengenai hubungan antarpribadi yang terjadi antara onselor dan konseli dalam situasi konseling. Hal ini sangat penting karena variable ini menyediakan kesempatan untuk menggarap berbagai masalah kesukaran konseli dalam proses hubungan, sehingga konseli dapat mengambil manfaat atau keuntungan melalui pengalaman ini. Konseli dapat belajar mengatur kembali hubungan antar pribadinya dan menemukan dirinya bahwa situasi konseling memungkinkan ia mengadakan konfrontasi, menunjukkan dirinya sendiri dan mengekspresikan perasaannya, baik yang positif maupun yang negatif kepada orang lain yang cukup aman. Dalam hal ini konselor merasa terbuka dan dapat mendorong konseli untuk berani menghadapi dirinya dan menunjukkan dirinya secara bebas. Inilah yang membuat konselor cepat merasa puas.

9. Aktualisasi (Self-Aktualisasi)

Konselor yang mampu mengaktualisasikan dirinya dirinya memiliki kemampuan mengadakan hubungan social yang hangat, intim, dan secara umum mereka sangat efektif dalam hidupnya.

Dari beberapa penjelasan di atas, secara umum jika berangkat dari berbagai pendapat dan penelitian sebelumnya, karakteristik kepribadian konselor yaitu hendaknya memiliki kemampuan berempati dengan baik terhadap berbagai kondisi dan permasalahan klien, memiliki respek dan keaslian kepada konseli yaitu dengan secara tidak langsung konselor dapat menghargai klien dan tidak berpura-pura.

Dalam menghadapi klien konselor memiliki kekongkretan menyatakan ekspresi mengenai perasaan dan pengalaman klien, melakukan konfrontasi dan dapat mengontrolnya dengan baik, dapat membuka diri serta menunjukkan kesanggupan diri dan menampakkan kekuatan pada penampilan pribadinya. Selalu memiliki memiliki kesiapan dan selalu mengaktualisasikan dirinya secara intim dan hangat kepada klien. Dari penjelasan yang telah dijelaskan di atas, konselor yang memiliki sifat kepribadian yang baik akan selalu meningkatkan kompetensi kepribadiannya secara terus menerus sehingga dapat tercermin dalam kegiatan kesehariannya.

Daradjat (2003: 26) mengemukakan guru yang ideal dalam pandangan remaja adalah guru yang mampu menjangkau perasaan remaja dan menghargai serta mendorong mereka untuk aktif dalam kegiatan sekolah serta suka memberikan penilaian yang objektif. guru yang terbuka hatinya untuk mendengarkan keluhan muridnya, bagi remaja dipandang sebagai konselor di sekolah itu. Hikmawati (2010: 63) menyatakan bahwa, harapan terbimbing, konseli/siswa sebagai individu yang sedang berada dealam proses proses berkembang atau menjadi (on becoming), yaitu berkembang ke arah kematangan atau kemandirian. Untuk mencapai kematangan tersebut, konseli memerlukan bimbingan karena mereka masih kurang memiliki pemahaman atau wawasan tentang dirinya dan lingkungannya juga pengalaman dalam menentukan arah kehidupannya.

Bimbingan dan konseling disediakan untuk memenuhi kebutuhan peserta didik. Namun kenyataan di lapangan menunjukkan bahwa siswa kurang memahami akan pentingnya layanan bimbingan dan konseling di sekolah, hal ini ditunjukkan dengan rasa malu atau takut yang dialami siswa untuk datang ke ruang bimbingan dan konseling. Ada kemungkinan hal ini berkaitan dengan kepribadian yang dimiliki konselor. Menurut Hikmawati (2010: 63) menumbuhkan pengharapan kepada konseli merupakan hal yang penti penting untuk dilakukan konselor. Namun pada kenyataannya, sering kali pengharapan yang diberikan oleh konselor adalah pengharapan semu. Untuk itu amatlah penting bagi konselor untuk bisa membedakan pengharapan semu dari pengharapan sejati.

Berdasarkan hasil penelitian yang dilakukan oleh Warsini (2008) tentang "Harapan siswa terhadap karakteristik kepribadian konselor di SMP Negeri Kota Malang" diperoleh hasil sangat banyak siswa $(99,71 \%)$ memiliki harapan terhadap kepribadian konselor pada indikator kompeten 


\section{KOMPETENSI KEPRIBADIAN KONSELOR}

secara profesional dan menjalankan perekembangan profesional dalam kategori sangat diharapkan, sedangkan secara khusus dapat disimpulkan sebagai berikut: (1) kepribadian konselor di sekolah yang sangat diharapkan oleh sebagian besar siswa meliputi 15 indikator yaitu: menunjukkan tanggung jawab orang lain, memiliki kepekaan, berempati, menghormati individu lain, memelihara kesehatan mental, mengonsep tindakan dan proses perubahan pada manusia secara sistematis, memfasilitasi perkembangan personal, mempunyai toleransi yang tinggi untuk stres dan frustasi, memilih kebebasan, berkomunikasi dengan efektif, kompeten secara profesional, memelihara kesehatan fisik dengan baik, menjalankan perkembangan profesional, memelihara identitas professional profesional sebagai konselor, dan mencontohkan etika profesional, (2) kepribadian konselor di sekolah yang diharapkan dinyatakan sebagian siswa meliputi 7 indikator yaitu: menunjukkan tanggung jawab orang lain, memiliki kepekaan, berempati, menghormati individu lain, memelihara kesehatan mental yang baik, mengonsep tindakan dan proses perubahan pada manusia secara sistematis, dan mempunyai toleransi yang tinggi untuk stres dan frustasi.

\section{Bimbingan dan Konseling}

Bimbingan dan konseling sebagai suatu proses bantuan yang dilakukan oleh konselor, guna menyelesaikan masalah siswa. Menurut Yusuf (2009: 37) bimbingan dan konseling merupakan terjemahan dari istilah "guidance" dan "counseling" dalam bahasa inggris". Senada dengan pendapat di atas Damayanti (2012: 9) mengungkapkan bimbingan dan konseling merupakan proses interaksi antara konselor dengan klien/konseli baik secara langsung (tatap muka) atau tidak langsung (melalui media: internet, atau telepon) dalam rangka membantu klien agar dapat membantu klien agar dapat mengembangkan potensi dirinya atau memecahakn masalah yang dialaminya.

Dari beberapa pengertian di atas, maka dapat disimpulkan bahwa Bimbingan dan Konseling adalah suatu proses pemberian bantuan yang dilakukan oleh konselor yang professional yaitu memiliki kemampuan memberikan bimbingan dan menyelesaikan masalah serta memiliki kompetensi kepribadian yang baik untuk menunjang keterlaksanaan bantuan serta layanan yang akan diberikan kepada setiap klien.

Penguasaan kompetensi kepribadian diharapkan proses bantuan bimbingan konseling dapat dijalankan oleh seorang konselor yang memiliki kemampuan pribadi yang tangguh, dapat menjalankan tugasnya penuh tanggung jawab, memiliki kesungguhan dan memiliki persiapan yang matang. Konselor yang memiliki kepribadian baik dan memiliki kompetensi kepribadian yang baik tentu dapat menunjang seorang konselor dalam membimbing dan membantu konseli dalam menyelesaikan permasalahan yang sedang dihadapinya.

Bimbingan dan konseling memiliki berbagai macam tujuan agar pelayanan Bimbingan dan Konseling dapat tercapai dengan baik, sehingga pelaksanaan layanan di sekolah dapat terlaksana dengan optimal. Bimbingan dan konseling memiliki tujuan umum dan tujuan khusus. Menurut Yusuf (2009: 49) diadakannya pemberian layanan bimbingan agar peserta didik dapat: 1) merencanakan kegiatan penyelesaian studi, perkembangan karir serta kehidupannya dimasa yang akan datang; 2) mengembangkan seluruh potensi dan kekuatan yang dimilikinya seoptimal mungkin; 3) menyesuaikan diri dengan lingkungan pendidikan, lingkungan masyarakat serta lingkungan kerjanya; 4) mengatasi hambatan dan kesulitan yang dihadapi dalam studi, penyesuaian dengan lingkungan pendidikan, masyarakat, maupun lingkungan kerja.

Secara khusus bimbingan dan konseling bertujuan untuk membantu siswa atau peserta didik agar dapat mencapai tugas-tugas perkembangannya yang meliputi aspek pribadi-sosial, belajar (akademik), dan karir. Dari pemaparan di atas dapat ditarik kesimpulan yaitu seorang konselor hendaknya dapat mengerti serta memahami tujuan dan proses bimbingan dan konseling itu sendiri dan dapat mengaplikasikan tujuan bimbingan dan konseling tersebut dalam proses kegiatan bimbingan dan konseling sehari-hari.

Dalam melaksanakan tujuan umum dan tujuan khusus dengan baik kepada peserta didik tentunya diberikan oleh seorang guru bimbingan dan konseling/konselor. Konselor yang akan memberikan layanan kepada peserta didik tentunya harus memahami tujuan dari layanan yang akan diberikan, dapat memahami tujuan bimbingan dan konseling dengan baik serta dapat memahami kondisi peserta didik dengan baik. Pelaksanaaan 


\section{FATMAWIJAYA}

tujuan bimbingan dan konseling, tidaklah lepas dari peran seorang konselor, yaitu konselor haruslah memiliki pengetahuan penunjang tentang kondisi fisiologis, psikologis dari peserta didik yang akan dihadapinya, untuk itu peran konselor dalam pelaksanaan tujuan bimbingan dan konseling amatlah penting, dan dibutuhkan konselor yang memiliki pemahaman dan memiliki kompetensi kepribadian yang baik pula dalam memberikan pelayanan terhadap peserta didik, baik dalam pelaksanaan tujuan umum dan khusus dalam tujuan bimbingan dan konseling.

Bimbingan dan konseling dilaksanakan dalam sekolah tentu memiliki berbagai macam fungsi yang dapat membantu siswa dalam proses belajar, berikut adalah berbagai macam fungsi bimbingan dan konseling. Menurut Suharsimi (2012: 37) menyatakkan bahwa fungsi bimbingan dan konseling adalah sebagai berikut: 1) fungsi pemahaman; 2) fungsi penyaluran dan penempatan; 3) fungsi penyesuaian; 4) fungsi pencegahan; 5) fungsi pengentasan, 6) fungsi pemeliharaan dan pengembangan.

Berdasarkan penjelasan tersebut dalam penerapan fungsi layanan bimbingan dan konseling hendaknya konselor memiliki kompetensi secara professional sehingga dapat melaksanakan fungsi layanan bimbingan dan konseling secara prosesional dan bertanggung jawab. Seorang konselor yang memiliki kompetensi kepribadian yang baik tentunya memiliki kemampuan membantu permasalahan siswa sesuai dengan sesuai dengan fungsi dan kebutuhan siswa tersebut, konselor dapat membedakan kebutuhan setiap peserta didik dan memiliki pengetahuan tentang perkembangan peserta didik serta dapat mengentaskan permasalahan siswa dan memperlakukan peserta didik secara individual.

Bidang bimbingan dan konseling terdapat beberapa butir yang mencangkup tentang aspek kehidupan diri maupun kehidupan sosialnya. Yusuf (2009: 51) mengemukakan bahwa terdapat empat bidang layanan bimbingan dan konseling yaitu: 1) bimbingan dan konseling akademik (belajar); 2) bimbingan dan konseling pribadi; 3) bimbingan dan konseling sosial; 4) bimbingan dan konseling karir. Berdasarkan pendapat tersebut, bahwa keempat bidang layanan bimbingan dan konseling, salah satunya ialah bidang bimbingan dan konseling pribadi. Dalam melaksanakan bimbingan dan konseling pribadi, hendaknya seorang konselor dapat memahami karakteristik maupun kualitas kepribadiannya terlebih dahulu sebelum seorang konselor melaksanakan layanan bimbingan dan konseling pribadi kepada konseli atau peserta didik. Sebab seorang konselor yang memiliki kepribadian baik tentunya sangat berpengaruh atas keberhasilan pelaksanaan layanan bimbingan dan konseling di sekolah.

Kepribadian merupakan kompetensi yang sangat penting dimiliki oleh konselor dalam meningkatkan komponen pembentukan profesionalisme sebagai guru pembimbing. Kompetensi kepribadian kiranya harus mendapatkan perhatian yang lebih, sebab kompetensi ini akan berkaitan dengan idealisme dan kemampuan untuk dapat memahami dirinya sendiri dalam kapasitas sebagai pendidik. Esensi kompetensi kepribadian konselor semuanya bermuara ke dalam pribadi konselor. Kompetensi pedagogik, profesional dan sosial yang dimiliki seorang konselor dalam melaksanakan pembelajaran, pada akhirnya akan lebih banyak ditentukan oleh kompetensi kepribadian yang dimilikinya.

Menguasai kompetensi kepribadian dengan baik, seorang konselor dapat mempengaruhi minat dan antusiasme anak dalam mengikuti kegiatan pembelajaran. Pribadi konselor yang santun, respek terhadap siswa, jujur, ikhlas dan dapat diteladani, mempunyai pengaruh yang signifikan terhadap keberhasilan proses layanan bimbingan dan konseling di sekolah, khususnya keberhasilan seorang konselor mengaplikasikan kompetensi kepribadiannya dalam proses konseling yang diberikan kepada konseli. Kompetensi pribadi konselor sangat berperan dan menjadi sangat penting dimiliki seorang konselor disekolah, mengingat tugas seorang konselor hendaknya dapat memahami konseli secara lebih mendalam, serta penunjang keberhasilan layanan bimbingan dan konseling yang ditujukan kepada siswa. Agar penelitian ini sesuai dengan tujuan yang diharapkan, maka dalam pelaksanaan penelitian penulis tidak sembarangan dalam melaksanakan penelitiannya tetapi juga harus menggunakan cara atau metode penelitian yang tepat agar dapat mencapai tujuan yang sudah ditetapkan sebelumnya. 


\section{KOMPETENSI KEPRIBADIAN KONSELOR}

\section{Metode Penelitian}

Penelitian ini merupakan jenis penelitian deskriptif, dalam penelitian ini telah ditetapkan dengan pendeskripsian data yang akan diperoleh tanpa mengadakan suatu perlakuan dan treatment tertentu. Dalam penelitian ini adalah untuk mengetahui kompetensi kepribadian konselor yang diharapkan siswa SMA Negeri 11 Yogyakarta Tahun Ajaran 2013/2014.

Subyek dalam penelitian ini berjumlah 169 siswa yang terdiri dari kelas X, XI dan kelas XII siswa SMA Negeri 11 Yogyakarta Tahun Ajaran 2013/2014, yang diambil dengan cara random sampling. Instrumen pengumpulan data pada penelitian ini menggunakan angket. Selanjutnya, teknik analisis data yang digunakan yaitu menggunakan penghitungan melalui pengelompokan kriteria kurang, sedang, dan baik. Untuk menguji validitas isi digunakan rumus product moment, sedangkan analisis uji reliabilitas menggunakan rumus alpha cronbach.

\section{Hasil Penelitian dan Pembahasan}

Hasil analisis data terhadap keseluruhan kompetensi kepribadian konselor yang diharapkan siswa SMA Negeri 11 Yogyakarta dilihat dari aspek beriman dan bertakwa kepada Tuhan Yang Maha Esa, aspek menghargai dan menjunjung tinggi nilai-nilai kemanusiaan, aspek individualitas dan kebebasan memilih, aspek menunjukkan integritas dan stabilitas kepribadian yang kuat dan pada aspek menampilkan kinerja berkualitas tinggi dan baik dapat dilihat pada tabel 1 .

Tabel 1

Distribusi Kategorisasi dan Tingkat Hasil Keseluruhan Penilaian Kompetensi Kepribadian Konselor yang Diharapkan Siswa

\begin{tabular}{llll}
\hline No & Interval Skor & Frekuensi & Kriteria \\
\hline 1 & 67 s.d 88 & 90 & Baik \\
2 & 45 s.d 66 & 79 & Sedang \\
3 & 22 s.d 44 & 0 & Kurang \\
& Total & 169 & - \\
\hline
\end{tabular}

Jika dilihat dalam masing-masing aspek dapat diketahui hasilsebagai berikut:

1. Aspek beriman dan bertakwa kepada Tuhan yang Maha Esa

Hasil pada aspek ini sesuai dengan harapan siswa terhadap kompetensi kepribadian konselor pada aspek beriman dan bertakwa Kepada Tuhan Yang Maha Esa. Skor hasil penilaian aspek beriman dan bertakwa kepada Tuhan Yang Maha Esa dapat dilihat pada tabel 2.

Tabel 2

Distribusi Kategorisasi dan Tingkat Hasil Penilaian Aspek Beriman dan Bertakwa Kepada Tuhan Yang Maha Esa

\begin{tabular}{cccc}
\hline $\mathrm{N}$ & Interval Skor & Frekuensi & Kriteria \\
\hline 1 & 181 s.d 240 & 85 & Baik \\
2 & 121 s.d 180 & 84 & Sedang \\
3 & 60 s.d 120 & 0 & Kurang \\
& Total & 169 & - \\
\hline
\end{tabular}

2. Aspek menghargai dan menjunjung tinggi nilai-nilai kemanusiaan, individualitas dan kebebasan memilih

Berdasarkan skor hasil penelitian diperoleh data bahwa aspek menghargai dan menjunjung tinggi nilai-nilai kemanusiaan, individualitas dan kebebasan memilih dikatakan baik, sesuai dengan harapan siswa terhadap kompetensi konselor pada aspek menghargai dan menjunjung tinggi nilai-nilai kemanusiaan, individualitas dan kebebasan memilih. Aspek menghargai dan menjunjung tinggi nilai-nilai kemanusiaan, individualitas dan kebebasan memilih masuk dalam kategori baik dan dapat dilihat pada tabel 3 .

Tabel 3

Distribusi Kategorisasi dan Tingkat Hasil Penilaian Aspek Menghargai dan Menjunjung Tinggi Nilai-Nilai Kemanusiaan, Individualitas, dan Kebebasan Memilih

\begin{tabular}{lccc}
\hline No & Interval & Frekuensi & Kriteria \\
\hline 1 & 31 s.d 40 & 72 & Baik \\
2 & 21 s.d 30 & 95 & Sedang \\
3 & 10 s.d 20 & 2 & Kurang \\
& Total & 169 & - \\
\hline
\end{tabular}

3. Aspek menunjukkan integritas dan stabilitas

Aspek menunjukkan integritas dan stabilitas kepribadian yang kuat masuk kategori baik. Data lebih rinci disajikan data dalam bentuk tabel 4 . 


\section{FATMAWIJAYA}

Tabel 4

Distribusi Kategorisasi dan Tingkat Hasil Penilaian Aspek Menunjukkan Integritas dan Stabilitas Kepribadian yang Kuat

\begin{tabular}{llcc}
\hline No & Interval Skor & Frekuensi & Kriteria \\
\hline 1 & 39 s.d 52 & 90 & Baik \\
2 & 27 s.d 38 & 76 & Sedang \\
3 & 13 s.d 26 & 3 & Kurang \\
& Total & 169 & - \\
\hline
\end{tabular}

4. Aspek menampilkan kinerja berkualitas tinggi Berdasarkan data hasil penelitian dapat diketahui bahwa kompetensi kepribadian konselor pada aspek menampilkan kinerja berkualitas tinggi sudah sesuai dengan yang diharapkan siswa. Hasil tersebut dapat diketahui dari tabel 5.

Tabel 5

Distribusi Kategorisasi dan Tingkat Hasil Penilaian Pada Aspek Menampilkan Kinerja Berkualitas Tinggi

\begin{tabular}{clcc}
\hline No & Interval & Frekuensi & Kriteria \\
\hline 1 & 45 s.d 60 & 84 & Baik \\
2 & 31 s.d 44 & 85 & Sedang \\
3 & 15 s.d 30 & 0 & Kurang \\
& Total & 169 & - \\
\hline
\end{tabular}

Berdasarkan hasil analisis secara keseluruhan terhadap kompetensi kepribadian konselor yang diharapkan siswa SMA Negeri 11 Yogyakarta masuk dalam kategori baik. Baik itu dilihat dari beberapa aspek yaitu, aspek beriman dan bertakwa kepada Tuhan yang Maha Esa, aspek menghargai dan menjunjung tinggi nilai-nilai kemanusiaan, individualitas dan kebebasan memilih, aspek menunjukkan integritas dan stabilitas kepribadian yang kuat, dan pada aspek menampilkan kinerja berkualitas tinggi.

Aspek beriman dan bertakwa kepada Tuhan yang Maha Esa masuk dalam kategori sedang. Untuk data lebih lanjut dapat disajikan data sebagai berikut: sebanyak 72 (43\%) harapan siswa tentang kompetensi kepribadian konselor pada aspek beriman dan bertakwa kepada tuhan yang maha esa masuk dalam kategori baik 95 (56\%) harapan siswa tentang kompetensi kepribadian konselor pada aspek beriman dan bertakwa kepada Tuhan Yang Maha Esa masuk dalam kategori sedang, dan 2 (1\%) harapan siswa tentang kompetensi kepribadian konselor masuk dalam kategori kurang. Dari data tersebut diketahui bahwa harapan siswa kepada kompetensi kepribadian konselor pada aspek beriman dan bertakwa kepada Tuhan Yang Maha Esa masuk dalam kategori sedang.

Aspek menghargai dan menjunjung tinggi nilai-nilai kemanusiaan, individualitas dan kebebasan memilih masuk dalam kategori baik. Sebanyak 90 (53\%) kompetensi kepribadian konselor yang diharapkan siswa pada aspek menghargai dan menjunjung tinggi nilai-nilai kemanusiaan, individualitas dan kebebasan memilih masuk dalam kategori baik, 79 (45\%) kompetensi kepribadian konselor yang diharapkan siswa pada aspek menghargai dan menjunjung tinggi nilai-nilai kemanusiaan, individualitas dan kebebasan memilih masuk dalam kategori sedang, dan $0(0 \%)$ kompetensi kepribadian konselor yang diharapkan siswa pada aspek menghargai dan menjunjung tinggi nilai-nilai kemanusiaan, individualitas dan kebebasan memilih kurang. Dari data tersebut diketahui bahwa aspek menghargai dan menjunjung tinggi nilai-nilai kemanusiaan, individualitas dan kebebasan memilih dikatan baik, sesuai dengan harapan siswa terhadap kompetensi konselor pada aspek menghargai dan menjunjung tinggi nilai-nilai kemanusiaan, individualitas dan kebebasan memilih.

Aspek menunjukkan integritas dan stabilitas kepribadian yang kuat masuk kategori baik. Sebanyak 90 (53\%) kompetensi kepribadian konselor yang diharapkan siswa pada aspek menunjukkan integritas dan stabilitas kepribadian yang kuat masuk dalam kategori baik, 76 (45\%) kompetensi kepribadian konselor yang diharapkan siswa pada aspek menunjukkan integritas dan stabilitas kepribadian yang kuat masuk dalam kategori sedang, dan 3 (2\%) kompetensi kepribadian konselor yang diharapkan siswa pada aspek menunjukkan integritas dan stabilitas kepribadian yang kuat masuk dalam kategori kurang. Dari data diketahui bahwa aspek menunjukkan integritas dan stabilitas kepribadian yang kuat masuk dalam kategori baik.

Aspek menampilkan kinerja berkualitas tinggi masuk kategori sedang. Sebanyak 84 (50\%) kompetensi kepribadian konselor pada aspek menampilkan kinerja berkualitas tinggi pada kategori baik, 85 (50\%) kompetensi kepribadian konselor pada aspek menampilkan kinerja 


\section{KOMPETENSI KEPRIBADIAN KONSELOR}

berkualitas tinggi pada kategori sedang dan $0(0 \%)$ kompetensi kepribadian konselor pada aspek menampilkan kinerja berkualitas tinggi pada kategori kurang. Dari data diketahui bahwa kompetensi kepribadian konselor pada aspek menampilkan kinerja berkualitas tinggi masuk dalam kategori sedang.

Melihat dari hasil pembahasan ini, diharapkan konselor/Guru Bimbingan dan Konseling di SMA Negeri 11 Yogyakarta pada khususnya dapat meningkatkan kompetensi kepribadian yang baik sesuai dengan harapan siswa yang menginginkan sosok konselor yang profesional dan memiliki kepribadian yang baik. Baik itu peningkatan pada kompetensi kepribadian yaitu pada aspek beriman dan bertakwa kepada Tuhan yang Maha Esa, pada aspek menghargai dan menjunjung tinggi nilainilai kemanusiaan, individualitas dan kebebasan memilih, pada aspek menunjukkan integritas dan stabilitas kepribadian yang kuat, maupun pada aspek menampilkan kinerja berkualitas tinggi.

\section{Simpulan}

Berdasarkan hasil analisis keseluruhan kompetensi kepribadian konselor yang diharapkan siswa SMA Negeri 11 Yogyakarta, maka dapat disimpulkan bahwa kompetensi kepribadian konselor yang diharapkan siswa SMA Negeri 11 Yogyakarta adalah baik, yaitu konselor yang memiliki kepribadian yang beriman dan bertakwa kepada tuhan yang maha esa, menghargai dan menjunjung tinggi nilai-nilai kemanusiaan, individualitas dan kebebasan memilih, dapat menunjukkan integritas dan stabilitas kepribadian yang kuat serta selalu menampilkan kinerja berkualitas tinggi. Informasi yang diperoleh dari hasil penelitian ini dapat dijadikan sebagai dasar pengembangan kompetensi kepribadian konselor agar menjadi konselor yang diharapkan oleh siswa. Konselor yang memiliki kepribadian sesuai harapan siswa dapat meningkatkan antusias siswa untuk mendapatkan layanan bimbingan dan konseling di sekolah.

\section{Referensi}

Azwar, Saifuddin. (2012). Reliabilitas dan Validitas. Yogyakarta: Pustaka Pelajar.

Hidayat, Herdi. (2013). Bimbingan dan Konseling Kesehatan Mental di Sekolah. Bandung: PT Remaja Rosdakarya
Hikmawati. (2010). Bimbingan Konseling. Jakarta: PT Rajagrafindo Persada

Komalasari, Gantina. (2011). Assessment Teknik Non Test dalam Perspektif Bimbingan dan Konseling Komprehensif. Bandung: Indeks

Mushaf, Jejen. ( 2011). Peningkatan Kompetensi Guru. Jakarta: Kencana Media Group.

Nidya. (2012). Buku Pintar Panduan Bimbingan dan Konseling. Yogyakarta: Araksa.

Rahmat, Hidayat. Jurnal tentang "persepsi siswa tentang pribadi konselor yang diharapkan siswa di smp negeri 2 tersono". di unduh pada Juni 2014.

Rosniati, Hakim. Jurnal tentang "Studi Islam Tentang Akhlak Konselor". Di unduh pada Juni 2014.

Saifuddin, Azwar. (2013). Metode Penelitian. Yogyakarta: Pustaka Pelajar

Sisrianti, Nurfarhanah, dan Yusri. Jurnal tentang "Persepsi Siswa tentang Kompetensi Kepribadian Guru Bimbingan dan konseling/konselor di SMP Negeri 5 Pariaman". Di unduh pada Juni 2014.

Sugiyono. (2013). Memahami Penelitian Kualitatif. Bandung: Alfabeta.

Sugiyono. (2013). Metode Penelitian Kombinasi. Bandung: Alfabeta.

Suharsimi Arikunto. (2010). Prosedur Penelitian Suatu Pendekatan Praktik. Jakarta: Rineka Cipta.

Suharsimi dan Lia Yuliana. (2012). Manajemen Pendidikan. Yogyakarta: Aditya Media.

Sukardi, Kusmawati. (2008). Proses Bimbingan Dan Konseling di Sekolah, untuk Memperoleh Angka Kredit. Jakarta: Rineka Cipta.

Sukmadinata, Nana Syaodih. (2012). Metode Penelitian Pendidikan. Bandung: PT Remaja Rosdakarya.

Tohirin. (2007). Bimbingan Dan Konseling di Sekolah dan Madrasah. Jakarta: PT Raja Grafindo Persada.

Warsini. (2008). Jurnal tentang "Harapan Siswa Terhadap Karakteristik Kepribadian Konselor di SMP Negeri Kota Malang” Di unduh pada Juni 2014.

Winkel dan Hastuti, (2007). Bimbingan dan Konseling di Insitusi Pendidikan. Yogyakarta: Media Abadi.

Yusuf, Syamsu, dan Juntika. (2010). Landasan Bimbingan Dan Konseling. Bandung: PT Remaja Rosdakarya. 


\section{FATMAWIJAYA}

Yusuf, Syamsu. (2009). Program Bimbingan dan Konseling di Sekolah. Bandung: Rizqi Press.
Zakiah, Daradjat. (2000). Remaja Harapan dan Tantangan. Jakarta: PT. Remaja Rosdakarya. 